Institut für Tierernährung

der Vetsuisse-Fakultät Universität Zürich

Direktorin: Prof. Dr. med. vet. Annette Liesegang

\title{
Influence of mastitis metritis agalactia (MMA) on bone and fat metabolism
}

\section{Inaugural-Dissertation}

zur Erlangung der Doktorwürde der

Vetsuisse-Fakultät Universität Zürich

vorgelegt von

Niklas Adrian Karst

Tierarzt aus

Scheuerfeld, Deutschland

genehmigt auf Antrag von

Prof. Dr. med. vet. Annette Liesegang 



\section{Contents}

Abstract

Zusammenfassung 5

Introduction

6

Material and Methods 7

$\underline{\text { Results }}$ 9

Discussion 10

Conclusion 13

Tables 14

References 19

Danksagung

Curriculum Vitae 


\begin{abstract}
Mastitis metritis agalactia (MMA) is a common disease in postpartum sows and has a negative effect on sows' longevity as well as on sows' and piglets' health. Since MMA often leads to reduced feed intake and an inflammatory state in general, which is known to affect bone metabolism, the aim of this study was to investigate the impact of MMA on bone and fat metabolism. The hypothesis was that it is possible to predict MMA by measuring ketone bodies and bone turnover markers. Blood samples from 175 sows (100 healthy \& 75 MMA sows) were taken within $72 \mathrm{~h}$ after farrowing. Serum was analysed for 25-0H-D, CTX-1, OC, ALP, Ca, Mg, P, PTH, triglycerides, BHB, leptin, TNF- $\alpha$, IL-6 and haptoglobin. MMA sows had a poorer BCS ( $\mathrm{p}<0.001)$ compared to healthy sows. MMA sows showed catabolic bone metabolism (increased serum CTX-I $(\mathrm{p}=0.004)$, decreased serum OC $(\mathrm{p}<0.001))$. Concentrations of serum $\mathrm{P}(\mathrm{p}=0.007)$, activity of ALP $(\mathrm{p}=0.002)$, and serum BHB concentrations $(\mathrm{p}=0.019)$ as well as serum concentration of TNF- $\alpha(p<0.001)$ and haptoglobin $(p=0.048)$ were increased in MMA sows. Serum Mg concentrations ( $<$ < 0.001) were decreased. Our results are in accordance with the known fact that sows are in an extreme catabolic state peripartum. This study demonstrates that bone metabolism in MMA sows is much more negatively affected than in healthy sows postpartum, due to inflammatory processes shown by higher concentrations of pro-inflammatory cytokines.
\end{abstract}

\title{
Keywords
}

bone metabolism, mastitis metritis agalactia, serum crosslaps, osteocalcin, cytokines 


\section{Zusammenfassung}

Mastitis Metritis Agalaktie wirkt sich negativ auf die Langlebigkeit von Sauen sowie auf die Gesundheit von Sau und Ferkeln aus. Da es meist zu einer verminderten Futteraufnahme kommt und Entzündungsprozesse sich auf den Knochenstoffwechsel auswirken können, bestand das Ziel dieser Studie darin, die Auswirkungen von MMA auf den Knochen- und Fettstoffwechsel zu untersuchen. Hypothese war, dass es möglich ist, MMA durch Messen von Ketonkörpern und Knochenstoffwechselmarkern vorherzusagen. Blut von 175 Sauen (100 gesunde \& 75 MMA-Sauen) wurden innerhalb von $72 \mathrm{~h}$ nach Abferkelung genommen. Serum wurde auf 25OH-D, CTX-1, OC, ALP, Ca, Mg, P, PTH, Triglyceride, BHB, Leptin, TNF- $\alpha$, IL-6 und Haptoglobin analysiert. MMA-Sauen hatten ein schlechteren BCS ( $p<0,001)$ und zeigten einen katabolen Knochenstoffwechsel (erhöhte CTX-I ( $\mathrm{p}=0,004)$ und erniedrigtes OC im Serum ( $\mathrm{p}$ $<0,001)$ ). Konzentrationen von Serum P $(p=0,007)$, Aktivität von ALP $(p=0,002), \operatorname{BHB}(\mathrm{p}=$ $0,019)$ sowie Serumkonzentrationen von TNF- $\alpha(p<0,001)$ und Haptoglobin $(p=0,048)$ waren in MMA-Sauen erhöht. Die Serum Mg Konzentrationen ( $p<0,001)$ waren verringert. Unsere Ergebnisse stimmen mit der bekannten Tatsache überein, dass sich Sauen peripartum in einem extrem katabolen Zustand befinden. Der Knochenstoffwechsel ist bei MMA-Sauen aufgrund von Entzündungsprozessen, die durch höhere Konzentrationen entzündungsfördernder Zytokine nachgewiesen wurden, weitaus negativer beeinflusst ist als bei gesunden Sauen nach der Geburt.

\section{Schlüsselwörter:}

Knochenstoffwechsel, Mastitis Metritis Agalaktie, Serum Crosslaps, Osteocalcin, Cytokine 


\section{INTRODUCTION}

Mastitis metritis agalactia (MMA) is seen as a severe form of postpartum dysgalactia syndrome (PPDS) (Martineau et al., 2012). It is a common disease in postpartum sows, which has a negative effect on sow longevity as well as on sows' and piglets' health.

Because the etiology and signs are numerous and vary from herd to herd, prevalence estimates are problematic to compare (Niemi, Bergman, Ovaska, Sevón-Aimonen, \& Heinonen, 2017). In Illinois, the prevalence of MMA ranged from $1.1 \%$ to $37.2 \%$ in pig herds with an average of 13\% (Bäckström, Morkoc, Connor, Larson, \& Price, 1984). According to a study in Belgium, $34 \%$ of herds had experienced problems which were related to PPDS/MMA (Papadopoulos, Vanderhaeghe, Janssens, Dewulf, \& Maes, 2010). A recent study in Switzerland showed an average herd level incidence of $37.4 \%$ in 20 affected swine farms (Pendl et al., 2017).

MMA is characterised by inflammation of the udder (mastitis), inflammation of the uterus (endometritis), and agalactia or, more precisely, dysgalactia. The consequence is a depression of lactation resulting in an insufficient supply of milk for piglets in the early days of life (Klopfenstein, Farmer, \& Martineau, 2006). The syndrome is responsible for an increase in mortality in piglets in the first days after birth, leading to a decrease in animal production and profitability (Bilkei, 2005). Since MMA is associated with an inflammation, an increase of cytokines and acute phase proteins can be seen in the blood (Mirko \& Bilkei, 2004; Zhu, Berg, Fossum, \& Magnusson, 2007). Measuring of these pro-inflammatory cytokines could therefore be used for detecting affected animals. MMA also affects sow longevity: 3-23\% of mortality in breeding sows is caused by mastitis and endometritis (D'Allaire, Stein, \& Leman, 1987; Christensen, Vraa-Andersen, \& Mousing, 1995). MMA is a multifactorial disease. Factors contributing to MMA include: poor hygiene, inappropriate feeding regime, inadequate water supply, body condition, and age (Hultén et al., 2004; Jenny, Vidondo, Pendl, Kümmerlen, \& Sidler, 2015; Maes, Papadopoulos, Cools, \& Janssens, 2010; Pendl et al., 2017). Nevertheless, as shown in the review by Gerjets \& Kemper (2009), MMA/PPDS is also found on farms with excellent management and optimised disinfection practices. Body condition score (BCS) at the time of farrowing plays a crucial role in the development of MMA. Sows, especially over conditioned ones, which are fed ad libitum with too little fiber before or directly after farrowing, are prone to constipation, which is known to be a risk factor for MMA (Göransson, 1989a; Oliviero, Kokkonen, Heinonen, Sankari, \& Peltoniemi, 2009).

In general, a dietary oversupply with energy during gestation leads to over conditioned sows at farrowing. Several studies have demonstrated that sows which gain too much weight in late gestation have lower feed intakes during lactation, which results in higher body reserve mobilisation during lactation (Dourmad, 1991; Mullan \& Williams, 1989; Weldon et al., 1994). To avoid environmental pollution, swine often receive a very low amount of dietary phosphorus (P), which may be at the lower limit of their requirements. Since foetuses grow rapidly in the last third of gestation (Knight, Bazer, Thatcher, Franke, \& Wallace, 1977; McPherson, Ji, Wu, Blanton Jr, \& Kim, 2004), the sow compensates for a nutritional P deficiency by absorption of $\mathrm{P}$ from the bone (Mahan, 1990). Calcium $(\mathrm{Ca})$ is released simultaneously with $\mathrm{P}$ and the bone thus becomes unstable (Liesegang, Loch, Bürgi, \& Risteli, 2005). In sows, markers for bone formation decrease at start of lactation and markers for bone resorption increase in late gestation and rise significantly after farrowing due to the start of lactation (van Riet et al., 2016). At the same time markers for bone resorption are increasing, osteocalcin (OC), a marker for bone formation, decreases. This reflects the increased requirements for skeletal development of foetuses and milk production, which dietary $\mathrm{Ca}$ and P may not meet (Liesegang et al., 2005; van Riet et al., 2016). Another interesting fact is the known connection between inflammation, respectively the increase in pro inflammatory cytokines, and bone metabolism. 
Especially TNF- $\alpha$ and IL-6 are known to be potent inducers of osteoclast differentiation and bone resorption (Hughes, Turner, Belibasakis, \& Martuscelli, 2006; Jilka, 1998). Haptoglobin, an acute phase protein, can also be linked to bone resorption (Lerner \& Fröhlander, 1992).

The hypothesis tested in this study meant to show if it is possible to predict the occurrence of MMA by measuring ketone bodies and bone turnover markers. Both parameters can indicate a catabolic state, which, in turn, negatively affects the immune system, making sows more susceptible to infections. Therefore, the aim of this study was to investigate the influence of MMA on bone and fat metabolism by comparing affected and healthy postpartum sows at the same time point in lactation.

\section{MATERIALS AND METHODS}

All experimental procedures were approved by the Swiss veterinary authority of the cantons of Lucerne (Switzerland, No. 02/2014) and Zurich (Switzerland, No. 92/2016) and were in accordance with the animal welfare laws of Switzerland.

\section{Farms and animals}

175 post-farrowing sows (100 healthy and 75 MMA sows) on 9 swine breeding farms (either Large White or Swiss Landrace) were included in this study. The farms were located in the cantons of Berne, Aargau, St.Gallen, Lucerne, and Thurgau. Farrowing patterns averaged 3 weeks and ranged from 2 to 6 weeks. The total number of animals kept per farm ranged from 44 to 210 sows. On each farm an average of 19 sows was sampled (ranging from 4 to 43 sows) depending on how often farms were visited and availability of sows. The age of the sampled sows ranged from 10 months to 5.7 years, with an average of 2.5 years. The animals were housed in farrowing pens according to Swiss animal welfare laws (Art. 50 Abs. 1 TSchV) with unrestricted access to water. The sows were fed twice per day with commercial complete feeds and had unlimited access to roughage in the form of hay or straw.

Sows were defined as affected by MMA when they had a rectal temperature equal to or above $39.5^{\circ} \mathrm{C}$ and showed one or more of the following clinical signs of MMA: such as a reddish or swollen udder indicating mastitis, agalactia / dysgalactia reported by the farmer or vaginal discharge indicating endometritis. Healthy animals were also clinically examined to exclude other disease states that could interfere with the results.

Age, litter size, BCS, and clinical signs of MMA were recorded for each sow.

\section{Collection and analysis of blood and urine samples}

Piglets were counted and separated from sows during sample collection. Blood samples were taken via jugular venipuncture (S-Monovette ${ }^{\circledR} 9 \mathrm{ml} Z$, Sarstedt, Nümbrecht, Germany and Bovivet $^{\circledR}$ disposable veterinary injection needle 14Gx33/4", Jørgen Kruuse A/S, Langeskov, Denmark) within $72 \mathrm{~h}$ after farrowing at $10 \mathrm{a}$.m. because of the circadian rhythm of OC. Wholeblood was immediately stored in a portable cooling box at a temperature of $2-4^{\circ} \mathrm{C}$ until processing in laboratory. Blood samples were centrifuged $\left(3000 \mathrm{x} \mathrm{g}\right.$ for $20 \mathrm{~min}$ at $\left.4^{\circ} \mathrm{C}\right)$ within one hour after sampling. Three $1.5 \mathrm{~mL}$ samples of serum were collected. Two were stored at $20^{\circ} \mathrm{C}$ and one at $-80^{\circ} \mathrm{C}$ for further analyses. Individual serum was analysed for $25-$ hydroxyvitamin D (25-(OH)-D), serum crosslaps (CTX-I), OC, alkaline phosphatase (ALP), $\mathrm{Ca}$, magnesium $(\mathrm{Mg}), \mathrm{P}$, parathyroid hormone $(\mathrm{PTH})$, triglycerides $(\mathrm{TG}), \mathrm{BHB}$, leptin, tumor necrosis factor alpha (TNF- $\alpha$ ), Interleukin 6 (IL-6) and haptoglobin. Analysis for 25-(OH)-D, CTX-I, OC, PTH, ALP, P, Mg, and BHB was performed as in previous studies, using test kits which have been evaluated for use in swine (Kolp et al., 2017; Liesegang et al., 2005; Schmid, 
2011). To determine activity of ALP and concentration of P, Mg, BHB and TG (ALP IFCC for ALP, PHOS for P, MG for Mg, TRIG for TG from Diatools AG, Villmergen, Switzerland, RANBUT for D-3-Hydroxybutyrate, Randox Laboratories Limited, Crumlin, County Antrim, BT29 4QY, United Kingdom) colorimetric measurement was performed with an autoanalyser (Cobas Mira Roche-autoanalyzer, F. Hoffman-La Roche Ltd., Basel, Switzerland). Leptin concentrations were determined using a commercial radioimmunoassay (RIA) test kit (MULTISPECIES LEPTIN RIA KIT for Leptin, Millipore, St. Charles, Missouri, USA) according to the manufacturer's instructions. TNF- $\alpha$ and IL-6 serum concentrations were determined using commercial immunoassays (Porcine TNF- $\alpha$ Immunoassay and Porcine IL-6 Immunoassay, both R\&D Systems, Inc., Minneapolis, Minnesota, USA). Haptoglobin was measured in sera with commercially available ELISA kits (PIG HAPTOGLOBIN ELISA, HAPT-9, Life Diagnostic, Inc., West Chester, Pennsylvania, USA). Serum Ca concentrations were determined by flame technique of atomic absorption spectrometry (AAS) using an atomic absorption spectrometer (High-Resolution Continuum Source Atomic Absorption Spectrometer, contrAA® 700, Analytik Jena, Germany). Spontaneous urine was collected in plastic containers from the sows before or after blood sampling. The $\mathrm{pH}$ value was measured immediately with a portable $\mathrm{pH}$ meter (MA130 Ion Meter, Mettler-Toledo AG, Schwerzenbach, Switzerland). After $\mathrm{pH}$ value measurement, the urine was stored in a portable cooling box at a temperature of $2-4^{\circ} \mathrm{C}$ until processing in the laboratory. One tube of urine was stored at $-20^{\circ} \mathrm{C}$ until analysis. $\mathrm{Ca}, \mathrm{P}$ and $\mathrm{Mg}$ were analysed using the same test as in serum after hydrolysis in hydrochloric acid. Creatinine (crea) was analysed using a commercially available test kit (CREA JAFFE, Diatools AG, Villmergen, Switzerland). For excretion of $\mathrm{Ca}, \mathrm{P}$, and $\mathrm{Mg}$ the results of these minerals were assessed in relation to crea.

\section{Collection and analysis of feed samples}

Feed samples of gestation and lactation diets and information about the feeding procedure were taken from each farm enrolled. Feed consumption was recorded on a herd basis and found to be acceptable if sows had an adequate BCS. The individual feed intake of each included sow was not recorded. Feed analysis was performed with a proximate analysis: contents of individual feed were tested for dry matter (DM), crude protein (CP), crude ash (CA), hydrochloric acid-insoluble ash (HCL-insoluble ash), ether extract (EE), and crude fiber (CF). For neutral detergent fiber (NDF), acid detergent fiber (ADF), and acid detergent lignin (ADL), the Van Soest fiber analysis was used (Van Soest, Robertson, \& Lewis, 1991). Ca, Mg, and P concentrations of the feedstuffs were determined in crude ash after hydrolysis in hydrochloric acid using the same test procedure as in serum. Gross energy was determined by an isothermic bomb calorimetry (IKA®-Kalorimetrie C 2000 basic, IKA® KV 600 digital, Staufen, Germany). For this purpose the feed samples were dried and then milled with a feed mill to a particle size of $1 \mathrm{~mm}$. A $0.5 \mathrm{~g}$ feed sample was burned in a quartz crucible using an ignition thread with defined calorific value.

\section{Calculation of diet}

Chemical composition of gestation and lactation diets was calculated using the results of the proximate analysis. Neither hay nor straw were included in the calculation, as there were no records regarding the amount of roughage fed. Individual lactation diets on each farm were summarised and are shown as an average diet for the healthy and MMA sows. Digestible energy (DE) of lactation diets was calculated via regression (Eidgenössische Volkswirtschaftsdepartement, Futtermittelbuch-Verordnung, Artikel 14, Anhang 8.6, 2011). Minimal digestible phosphorus was estimated with $65 \%$ in diets with greater than 500 units of phytase activity (FYT) (DLG, 1999). In diets without phytase, minimal digestible phosphorus 
was estimated based on ingredients (Kamphues et al., 2014). Values of digestible phosphorus must be seen as estimations. The diets were calculated for a primiparous sow weighing $180 \mathrm{~kg}$ having 12.9 piglets and a multiparous sow weighing $240 \mathrm{~kg}$ having 12.9 piglets.

\section{Statistical analyses}

Statistical analyses were performed with R (https://cran.r-project.org). A multivariable logistic regression analysis was undertaken with disease status (MMA or healthy) as the dependent variable. Neither age, number of farrowings nor litter size were significant so were removed from the analysis. Body condition score was highly significant with MMA affected sows having a lower score ( $\mathrm{p}<0.001)$. The odds ratios $(\mathrm{OR}), 95 \% \mathrm{CI}$ of the ORs and $\mathrm{p}$ values of the serum parameters are given when controlled for BCS by including BCS in each analysis. Statistical significance was set to $\mathrm{p}<0.05$ for all analyses.

\section{RESULTS}

\section{Animals}

In total 175 sows were included in this study. 24 sows were primiparous and 151 were multiparous. $66.7 \%$ of primiparous sows showed signs of MMA. The age of sampled sows ranged from 10 month to 5.7 years. There was no difference in age, number of farrowings and number of suckling piglets between MMA and healthy sows. MMA was associated with a poorer body condition score $(\mathrm{p}<0.001)$ compared to healthy sows (Table 1). MMA sows also showed a greatly decreased feed intake as observed by farmers.

\section{Diet}

Average composition of the lactation diet, as given in Table 2, corresponded to a commercially available lactation diet. Calculations of an average lactation diet for a sow with $240 \mathrm{~kg}$ of bodyweight and 12.9 suckling piglets (Table 3) showed that gross protein requirements exceeded the nutritional recommendations on average up to $14.75 \%$, with satisfied energy requirement. $\mathrm{Ca}$ and $\mathrm{P}$ requirements were fully covered with sufficient energy supply. Estimated digestible phosphorus also met recommendations. Average composition of the gestation diet showed three major differences compared to the lactation diet: higher content of crude fiber, lower content of protein, and lower digestible energy (Table 2).

\section{Blood samples}

\section{Bone markers, minerals, TNF- $\alpha$, IL-6 and haptoglobin in serum}

Table 4 shows that MMA was associated with higher serum concentrations of CTX-I ( $\mathrm{p}=$ $0.004)$, lower serum concentrations of OC $(\mathrm{p}<0.001)$, higher serum concentrations of $\mathrm{P}(\mathrm{p}=$ $0.007)$ and higher serum activity of ALP $(p=0.002)$. Serum Ca concentrations was not influenced by MMA. Serum concentrations of $\mathrm{Mg}$ were lower $(\mathrm{p}=0.001)$ in MMA sows compared to healthy sows. Higher serum concentrations of TNF- $\alpha(p<0.001)$ and haptoglobin $(p=0.048)$ were found in MMA sows. Serum concentration of IL-6 did not differ between MMA and healthy sows.

\section{5-(OH)-D and PTH in serum}

MMA was associated with lower 25-(OH)-D serum concentrations $(\mathrm{p}=0.043)$ and higher PTH serum concentrations $(\mathrm{p}=0.003)$ (Table 4$)$. 


\section{Parameters for fat and energy metabolism in serum}

TG serum concentrations in MMA and healthy sows did not differ. MMA was associated with higher BHB serum concentrations $(\mathrm{p}=0.019$, (Table 4). Leptin serum concentrations did not differ between MMA sows and healthy ones.

\section{Urine samples}

From 175 sows, 124 spontaneous urine samples were collected. The $\mathrm{pH}$ value ranged from 4.72 - 8.09. No difference between healthy and MMA sows was noticed. Renal excretion of P (P/crea) did not differ between MMA and healthy sows. Excretion of $\mathrm{Ca}(\mathrm{Ca} / \mathrm{crea})$ and $\mathrm{Mg}$ (Mg/crea) were lower in the MMA sows (Table 5).

\section{DISCUSSION}

\section{Animals}

In this study, the authors defined sows being MMA positive when rectal body temperature was greater or equal to $39.5^{\circ} \mathrm{C}$ in combination with at least one or more clinical signs of MMA (e.g. mastitis, agalactia, vaginal discharge, anorexia). Many studies have shown that body temperature can be higher than $40^{\circ} \mathrm{C}$ in healthy sows after farrowing (De Braganca, Mounier, Hulin, \& Prunier, 1997; Kelley \& Curtis, 1978), which means a higher temperature after farrowing is not necessarily an indication for MMA, but may simply be a consequence of lactation hyperthermia (Ulmershakibaei \& Plonait, 1992). Therefore, high body temperature should not be used alone to determine the presence of MMA (Martineau et al., 2012). In this study, the case definition for a sow with MMA used a combination of temperature and clinical signs of MMA. Determination of pro-inflammatory cytokines (TNF- $\alpha$, IL-6) which are known to be increased in animals with inflammatory diseases (Kruse, Essén-Gustavsson, Fossum, \& Jensen-Waern, 2008; Zhu, Fossum, Berg, \& Magnusson, 2007; Zhu, Österlundh, Hultén, \& Magnusson, 2004) and the acute phase protein haptoglobin, which also can be a marker for an inflammatory state in sows was assessed to show the connection between inflammation and bone metabolism. As previously written, over conditioned sows at the time of farrowing have been shown to have an increased risk for developing MMA. It was therefore surprising that MMA sows had a poorer BCS compared to healthy sows in this study. Since sows were only observed during sampling, we can only guess that the lower BCS might be a reflection of a lower rank in social hierarchy and that these sows could not access enough food in group housing systems. One can also assume that these low-ranking sows are more stressed, which could have a negative effect on their immune system, making them more susceptible to infectious diseases. However, there are many controversial studies on stress and immune status in swine. Since stress can suppress, enhance, or have no effect on the immune status of swine (Salak-Johnson \& McGlone, 2007) and we did not evaluate any stress parameters in this study, this must be seen as an assumption. A difficulty in comparing BCS between animals in general is the low correlation of back fat thickness and BCS in primiparous sows and at farrowing (Maes, Janssens, Delputte, Lammertyn, \& de Kruif, 2004). In contrast to BCS, back fat thickness correlates well with the total amount of body fat (Mullan \& Williams, 1990), so visually estimated "thinner" animals could have more body fat than "fatter" ones.

\section{Diet}

Higher contents of crude fiber in pre-farrowing diets are known to reduce the risk of constipation (Oliviero et al., 2009) and the occurrence of MMA (Göransson, 1989b; Sarandan, Neufeld, \& Neufeld, 2008). The diets, which were fed to sows before farrowing in our study, 
contained a high content of crude fiber, which fell within reference values and recommendations for fiber content in diets for pregnant sows (LfL-Information, 2014). Calculations of the lactation diet showed that it could be difficult, especially for younger or lighter sows, to consume enough feed to meet their energy requirement at the start of lactation, primarily due to limited dry matter intake (Kamphues et al., 2014). Restrictive feeding after farrowing is, however, a very common practice, as ad libitum feeding immediately after farrowing is considered a risk factor for MMA (Neil, Ogle, \& Anner, 1996; Papadopoulos et al., 2010). Since the farmers in this study increased the daily supply of feed over a few days post-farrowing until the energy demand was met, it must be considered that the sows may have been unable to meet their energy requirements during the sampling.

\section{Bone markers, minerals, TNF- $\alpha$, IL-6 and haptoglobin in serum}

Bone markers (CTX-I, OC) showed significant differences between MMA and healthy sows. It is well known that markers for bone resorption increase at the end of gestation due to the rapid growth of the foetuses and at the beginning of lactation in several species including swine (Liesegang et al., 2005; van Riet et al., 2016), ruminants (Liesegang et al., 2000; Liesegang, Risteli, \& Wanner, 2007), equine (Filipović, Stojević, Prvanović, \& Tuček, 2010), and humans (Kaur et al., 2003; Naylor, Iqbal, Fledelius, Fraser, \& Eastell, 2000). In this study, MMA affected sows showed a catabolic bone metabolism, which can be linked to higher serum concentrations of pro- inflammatory cytokines. As demonstrated in previous studies, mammary glands of sows can produce and secrete cytokines (Zhu et al., 2004; Zhu et al., 2007). Higher serum CTX-I concentrations can be explained by inflammatory processes that exist in sows suffering from MMA. Especially TNF- $\alpha$ is known to be potent inducer of osteoclast differentiation and bone resorption (Hughes et al., 2006; Jilka, 1998). TNF- $\alpha$ also inhibits osteoblast function, differentiation, and osteocalcin expression (Hughes et al., 2006; Nanes, 2003), so lower serum OC concentrations in MMA sows are not surprising. In contrast to an earlier study (Stiehler, Heuwieser, Pfützner, \& Burfeind, 2016), but in accordance to the study of Mirko \& Bilkei (2004), MMA sows showed higher haptoglobin levels than healthy sows. Due to the contradictory results, it remains to be seen if haptoglobin can be used as a marker in MMA sows. Higher serum ALP activity in MMA sows could be explained by an increased bone metabolism. Additionally, age of the animals can have an influence on ALP activity, since serum ALP activity is generally higher in growing animals because of bone metabolism. (Kierek-Jaszczuk \& Zurkowski, 1980; Merk, 1992). However, there was no difference in age between MMA and healthy sows and there are different isoenzymes of ALP. Since we measured the activity of total ALP, we cannot be certain that the increase of ALP activity in MMA sows is solely due to bone metabolism. Serum Ca concentrations did not differ between MMA and healthy sows and remained within the normal reference range for sows (Friendship, Lumsden, McMillan, \& Wilson, 1984). This is in contrast to previously conducted studies that have shown a decrease in serum Ca concentration in MMA sows (Baer \& Bilkei, 2005; Hermansson, Einarsson, Ekman, \& Larsson 1978; Plonait, 2004) but could be explained by higher serum PTH concentration MMA sows showed in this study, which will be mentioned later. Serum P concentrations in both, healthy and MMA sows, were within the lower reference range (Friendship et al., 1984; Verheyen et al., 2007). Since serum P concentration is dependent on the supply of dietary P (Girard, Robert, Matte, Farmer, \& Martineau, 1996), low serum P concentrations are reflective of low dietary $\mathrm{P}$. The estimated content of digestible $\mathrm{P}$ of the fed diet was just above the requirement, so the true supply of dietary $\mathrm{P}$ could have been lower and a reason for rather low serum $\mathrm{P}$ concentrations. An explanation for higher serum $\mathrm{P}$ concentrations in MMA sows could be higher $\mathrm{P}$ mobilisation from the bone due to increased bone resorption, which can be verified by higher levels of CTX-I. Older studies showed a rise 
of serum $\mathrm{P}$ concentration during the immediate postpartum period after injection of endotoxins (Nachreiner, Garcia, \& Ginther, 1972). These results can be linked to the effect of cytokines on bone metabolism (Jilka, 1998). The lower serum Mg concentration in MMA sows in our study is consistent with results from earlier studies (Baer \& Bilkei, 2005; Hermansson et al., 1978). We also assume that lower $\mathrm{Mg}$ serum concentrations are a result of decreased feed intake (Hermansson et al., 1978; National Research Council, 2012), since requirements should have been met by the diet. The Mg serum concentrations of healthy and MMA sows in our study, however, remained within the normal reference range for lactating sows (Seutter, 1995).

\section{5-(OH)-D and PTH in serum}

25-(OH)-D serum concentrations, which represents an adequate vitamin D supply in animals, were lower in MMA sows but remained within the normal reference range for sows (Goff, Horst, \& Littledike 1984; Madson et al., 2012). Sources of vitamin D for swine include diet and sunlight (Kolp, Wilkens, Pendl, Eichenberger, \& Liesegang, 2017). Since the sows in this study were not exposed to direct sunlight, we assume that $25-(\mathrm{OH})-\mathrm{D}$ requirements were fully met by the diet. Previous studies have shown that activation of immune system does not affect 25$(\mathrm{OH})$-D serum concentration (Wang et al., 2006). It remains unclear why MMA sows showed lower 25-(OH)-D serum concentrations in this study. Higher serum PTH concentration in MMA sows could be a cause for the lower $\mathrm{Ca}$ excretion in urine they showed since PTH leads to a higher reabsorption of $\mathrm{Ca}$ in the kidney (Boros, Bindels, \& Hoenderop, 2009; Van Abel et al., 2005). Even though older studies have observed a decrease in serum Ca concentration in MMA affected sows (Baer \& Bilkei, 2005; Hermansson et al., 1978; Plonait, 2004) serum Ca concentrations did not differ between MMA and healthy sows in this study. This also could be explained by the higher serum PTH concentrations in the MMA sows.

\section{Parameters for fat and energy metabolism in serum}

During prolonged starvation, ketone bodies are formed to ensure supply of the heart, skeletal muscles, and brain when glucose reserves are depleted (Nelson et al., 2017). Higher serum BHB concentrations in sows with MMA could be a reflection of a negative energy balance. Individual feed intake of sows was not recorded, but all MMA sows showed a greatly reduced feed intake in this study. Increased serum BHB concentration when feed intake decreases and sows do not consume adequate energy to meet their needs has been demonstrated in previous studies (Alsop, Hurnik, \& Bildfell, 1994; Luimes, Simpson, \& Wideman, 2012). There was a trend towards lower TG serum levels in MMA sows; however, the values always stayed within the normal reference range for sows (Bickhardt, 1992; Ruiz, Ewan, \& Speer, 1971). We suspect that the slightly lower serum TG values in MMA affected sows are due to decreased feed intake and high energy requirements. Leptin is known to decrease in times of starvation and negative energy balance in humans, rodents, and swine (Houseknecht, Baile, Matteri, \& Spurlock 1998; Spurlock et al., 1998a; Spurlock et al., 1998b). Sows affected by MMA showed a greatly reduced feed intake and were in a negative energy balance so we would have expected them to have lower serum leptin concentrations, however, serum leptin concentrations did not differ between MMA and healthy sows in this study.

\section{Urine samples}

Excretion of $\mathrm{Ca}$ in urine was lower in the MMA sows. The reason for this could be the higher serum PTH concentrations and the effect of PTH on renal Ca reabsorption (Boros et al., 2009; Van Abel et al., 2005). Higher renal reabsorption of Ca could possibly explain why mean serum 
Ca concentration was as high in the MMA sows as in healthy sows. Results of older studies, however, have shown lower serum Ca concentrations in MMA sows (Baer \& Bilkei, 2005; Hermansson et al., 1978). Excretion of Mg was lower in the MMA sows. We assume this is a direct consequence of lower serum Mg concentrations measured in MMA affected sows.

\section{CONCLUSION}

Countless investigations have already been carried out to give veterinarians an understanding of the MMA disease complex. Our results are in accordance with the known fact that sows are in an extreme catabolic state around farrowing. In addition, this study demonstrates that bone metabolism in MMA sows is much more negatively affected than in healthy sows after farrowing due to inflammatory processes shown by higher concentrations of pro-inflammatory cytokine and the acute phase protein, haptoglobin. Further studies are needed to assess whether all the altered serum parameters are a cause or a consequence of MMA; however, extreme changes in serum CTX-I and OC concentrations could be indicative of an increased risk of developing MMA. 
TABLES

Table 1: Age, farrowings, litter, BCS,

$$
\text { Healthy }
$$

MMA OR

CI

$\mathrm{p}$ value

\begin{tabular}{|c|c|c|c|c|c|}
\hline Number of sows & 100 & 75 & & & \\
\hline $\mathrm{Age}^{1}$ & $2.63 \pm 1.10$ & $2.29 \pm 1.40$ & - & - & n.s. \\
\hline $\begin{array}{l}\text { Number of } \\
\text { farrowings }\end{array}$ & $4.86 \pm 2.51$ & $4.01 \pm 2.76$ & - & - & n.s. \\
\hline Number of piglets & $12.84 \pm 3.36$ & $12.88 \pm 2.60$ & - & - & n.s. \\
\hline BCS & $3.34 \pm 0.49$ & $3.03 \pm 0.47$ & 0.233 & $0.111-0.490$ & $<0.001$ \\
\hline
\end{tabular}

Mean \pm SD, Odds ratio: OR, 95\% confidence interval: CI, Not significant: n.s.

${ }^{1}$ in years 
Table 2: Chemical composition of diets without hay or straw, Mean \pm SD

\begin{tabular}{|c|c|c|c|}
\hline lactation diet & $\begin{array}{l}\text { reference } \\
\text { values for } \\
\text { lactation } \\
\text { diets } t\end{array}$ & gestation diet & $\begin{array}{c}\text { reference values } \\
\text { for late gestation } \\
\text { diets } \dagger,+\end{array}$ \\
\hline
\end{tabular}

\begin{tabular}{lcccc}
\hline Dry matter, \% & $91.8 \pm 1.37$ & & $92.1 \pm 1.1$ & \\
Crude ash, \% & $6.30 \pm 0.67$ & & $6.59 \pm 1.05$ & \\
Crude protein, \% & $18.4 \pm 1.50$ & $15.8-17 \dagger$ & $16.6 \pm 1.96$ & $11.6-12.2 \dagger$ \\
Crude fat, \% & $6.70 \pm 1.74$ & & $6.12 \pm 2.83$ & \\
Crude fiber, \% & $5.70 \pm 1.49$ & $4 \dagger$ & $8.73 \pm 2.37$ & $>7 \dagger$ \\
$\mathrm{NfE}^{1}, \%$ & $54.6 \pm 3.90$ & & $54.0 \pm 3.67$ & \\
$\mathrm{Ca}, \%$ & $0.98 \pm 0.16$ & $0.87-0.94 \dagger$ & $0.84 \pm 0.19$ & $0.77-0.81 \dagger$ \\
$\mathrm{P}, \%$ & $0.54 \pm 0.07$ & $0.53-0.57 \dagger$ & $0.53 \pm 0.04$ & $0.46-0.49 \dagger$ \\
$\mathrm{DE}, \mathrm{MJ}$ & $13.3 \pm 0.79$ & $13.2-14.2 \dagger$ & $12.0 \pm 0.93^{2}$ & $11.6-12.2 \dagger$ \\
\hline
\end{tabular}

†Agroscope, 2016. Fütterungsempfehlungen für Schweine (Gelbes Buch). Access:

https://www.agroscope.admin.ch/agroscope/de/home/services/dienste/futtermittel/fuetterungs empfehlungen-schweine.html, last access 04.07.2018

$\neq$ LfL-Information, 2014: Futtermittelberechnung für Schweine, $21^{\text {st }}$ edition

${ }^{1}$ nitrogen-free extracts

2 average energy values on feed labels 
Table 3: Average diet for a sow with $240 \mathrm{~kg}$ of bodyweight and 12.9 suckling piglets (energy coverage was assumed), Mean \pm SD

\begin{tabular}{lcc}
\hline \hline & Diet & Reference values† \\
\hline Dry matter, kg & $6.99 \pm 0.35$ & \\
Crude ash, kg & $0.48 \pm 0.08$ & 1.22 \\
Crude protein, kg & $1.40 \pm 0.15$ & \\
Crude fat, kg & $0.53 \pm 0.15$ & \\
Crude fiber, kg & $0.44 \pm 0.13$ & 102.04 \\
Digestible energy, MJ & 102.04 & \\
Ca, g & $75.0 \pm 13.59$ & \\
P, g & $41.6 \pm 6.78$ & \\
Digestible P, g & $23.9 \pm 3.7$ & $0.4-1.7$ \\
Mg/DM, g/kg & $2.74 \pm 0.46$ & 0.66 \\
Ca/DE, g/MJ & $0.73 \pm 0.14$ & 0.4 \\
P/DE, g/MJ & $0.41 \pm 0.07$ & 0.2 \\
Digestible P/DE, g/MJ & $0.23 \pm 0.04$ & \\
\hline
\end{tabular}

†Agroscope, 2016. Fütterungsempfehlungen für Schweine (Gelbes Buch). Access: https://www.agroscope.admin.ch/agroscope/de/home/services/dienste/futtermittel/fuetterungs empfehlungen-schweine.html, last access 04.07.2018 
Table 4: Results of blood serum analysis

Healthy

MMA

OR

CI

$\mathrm{p}$ value

\begin{tabular}{|c|c|c|c|c|c|}
\hline $\mathrm{Ca}, \mathrm{mmol} / \mathrm{l}$ & $2.42 \pm 0.19$ & $2.40 \pm 0.16$ & - & - & n.s. \\
\hline $\mathrm{P}, \mathrm{mmol} / \mathrm{l}$ & $1.60 \pm 0.39$ & $1.73 \pm 0.38$ & 3.37 & $1.39-8.14$ & 0.007 \\
\hline $\mathrm{Mg}, \mathrm{mmol} / \mathrm{l}$ & $0.79 \pm 0.10$ & $0.72 \pm 0.16$ & 0.01 & $0.001-0.169$ & 0.001 \\
\hline ALP, U/1 & $42.11 \pm 22.40$ & $59.61 \pm 33.26$ & 1.03 & $1.009-1.043$ & 0.002 \\
\hline PTH, pg/ml & $5.46 \pm 3.50$ & $8.58 \pm 9.14$ & 1.11 & $1.035-1.181$ & 0.003 \\
\hline CTX-I, ng/ml & $0.53 \pm 0.32$ & $0.72 \pm 0.35$ & 4.47 & $1.615-12.37$ & 0.004 \\
\hline $\mathrm{OC}, \mathrm{ng} / \mathrm{ml}$ & $84.03 \pm 46.67$ & $59.22 \pm 45.02$ & 0.987 & $0.979-0.994$ & $<0.001$ \\
\hline $25-(\mathrm{OH})-\mathrm{D}, \mathrm{nmol} / \mathrm{l}$ & $\begin{array}{c}239.01 \pm \\
126.04\end{array}$ & $202.17 \pm 82.09$ & 0.997 & $0.994-0.999$ & 0.043 \\
\hline $\mathrm{TG}, \mathrm{mmol} / \mathrm{l}$ & $0.26 \pm 0.11$ & $0.24 \pm 0.12$ & - & - & n.s. \\
\hline $\mathrm{BHB}, \mu \mathrm{mol} / 1$ & $12.71 \pm 8.20$ & $31.03 \pm 72.08$ & 1.035 & $1.006-1.066$ & 0.019 \\
\hline Leptin, ng/ml & $14.51 \pm 7.83$ & $11.55 \pm 6.36$ & - & - & n.s. \\
\hline TNF- $\alpha, p g / m l$ & $63.60 \pm 25.22$ & $\begin{array}{c}191.98 \pm \\
311.21\end{array}$ & 1.023 & $1.010-1.035$ & $<0.001$ \\
\hline IL-6, pg/ml & $33.86 \pm 35.04$ & $\begin{array}{c}133.97 \pm \\
342.62\end{array}$ & - & - & n.s. \\
\hline Haptoglobin, $\mathrm{mg} / \mathrm{ml}$ & $1.87 \pm 0.48$ & $2.10 \pm 0.62$ & 1.845 & $1.005-3.388$ & 0.048 \\
\hline
\end{tabular}

Mean \pm SD, Odds ratio: OR, 95\% confidence interval: CI, Not significant: n.s. 
Table 5: Results of urine analysis

$$
\text { Healthy }
$$

MMA

OR

CI

$\mathrm{p}$ value

\begin{tabular}{lccccc}
\hline $\mathrm{Ca} / \mathrm{crea}, \mathrm{mmol} / \mathrm{l}$ & $0.58 \pm 0.64$ & $0.21 \pm 0.43$ & 0.135 & $0.040-0.462$ & 0.001 \\
$\mathrm{P} / \mathrm{crea}, \mathrm{mmol} / \mathrm{l}$ & $0.27 \pm 0.39$ & $0.35 \pm 0.47$ & - & - & n.s. \\
$\mathrm{Mg} / \mathrm{crea}, \mathrm{mmol} / \mathrm{l}$ & $1.19 \pm 0.81$ & $0.72 \pm 1.29$ & 0.372 & $0.180-0.770$ & 0.008
\end{tabular}

Mean \pm SD, Odds ratio: OR, 95\% confidence interval: CI, Not significant: n.s. 


\section{References}

Alsop, J. E., Hurnik, D., \& Bildfell, R. J. (1994). Porcine ketosis: A case report and literature summary. Journal of Swine Health and Production, 2, 5-8.

Bäckström, L., Morkoc, A. C., Connor, J., Larson, R., \& Price, W. (1984). Clinical study of mastitis-metritis-agalactia in sows in Illinois. Journal of the American Veterinary Medical Association, 185(1), 70-73.

Baer, C., \& Bilkei, G. (2005). Ultrasonographic and gross pathological findings in the mammary glands of weaned sows having suffered recidiving mastitis metritis agalactia. Reproduction in domestic animals, 40(6), 544-547. doi:10.1111/j.1439$\underline{0531.2005 .00629 . \mathrm{x}}$

Bickhardt, K. (1992). Kompendium der allgemeinen Inneren Medizin und Pathophysiologie für Tierärzte: mit 15 Tabellen. Parey.

Bilkei, G. (2005). The course of acute-phase proteins and serum cortisol in mastitis metritis agalactia (MMA) of the sow and sow performance. Tijdschrift voor diergeneeskunde, $130(2), 38-41$.

Boros, S., Bindels, R. J., \& Hoenderop, J. G. (2009). Active $\mathrm{Ca}^{2+}$ reabsorption in the connecting tubule. Pflügers Archiv-European Journal of Physiology, 458(1), 99-109. doi: $\underline{10.1007 / \mathrm{s} 00424-008-0602-6}$

Christensen, G., Vraa-Andersen, L., \& Mousing, J. (1995). Causes of mortality among sows in Danish pig herds. The Veterinary Record, 137(16), 395-399. doi:10.1136/vr.137.16.395

D'Allaire, S., Stein, T. E., \& Leman, A. D. (1987). Culling patterns in selected Minnesota swine breeding herds. Canadian Journal of Veterinary Research, 51(4), 506.

De Braganca, M. M., Mounier, A. M., Hulin, J. C., \& Prunier, A. (1997). La sous-nutrition explique-t-elle les effets d'une temperature ambiante elevee sur les performances des truies?. JOURNEES DE LA RECHERCHE PORCINE EN FRANCE, 29, 81-88.

DLG (1999). Schweinefütterung auf der Basis des verdaulichen Phosphors, DLGInformationsschrift, 1/1999.

Dourmad, J. Y. (1991). Effect of feeding level in the gilt during pregnancy on voluntary feed intake during lactation and changes in body composition during gestation and lactation. Livestock Production Science, 27(4), 309-319. doi:10.1016/0301-6226(91)90126-B

Eidgenössisches Volkswirtschaftsdepartement (2011). Verordnung über die Produktion und das Inverkehrbringen von Futtermitteln, Futtermittelzusatzstoffen und Diätfuttermitteln [PDF file]. Retrieved from http://www.admin.ch/opc/de/officialcompilation/2011/5699.pdf

Filipović, N., Stojević, Z., Prvanović, N., \& Tuček, Z. (2010). The influence of late pregnancy and lactation on bone metabolism in mares. Research in veterinary science, 88(3), 405410. doi:10.1016/j.rvsc.2009.11.008 
Friendship, R., Lumsden, J. H., McMillan, I., \& Wilson, M. R. (1984). Hematology and biochemistry reference values for Ontario swine. Canadian journal of comparative medicine, 48(4), 390.

Gerjets, I., \& Kemper, N. (2009). Coliform mastitis in sows: a review. Journal of Swine Health and Production, 17(2), 97-105.

Girard, C. L., Robert, S., Matte, J. J., Farmer, C., \& Martineau, G. P. (1996). Serum concentrations of micronutrients, packed cell volume, and blood hemoglobin during the first two gestations and lactations of sows. Canadian journal of veterinary research, 60(3), 179.

Goff, J. P., Horst, R. L., \& Littledike, E. T. (1984). Effect of sow vitamin D status at parturition on the vitamin D status of neonatal piglets. The Journal of nutrition, 114(1), 163-169. doi: $10.1093 / \mathrm{jn} / 114.1 .163$

Göransson, L. (1989a). The effect of feed allowance in late pregnancy on the occurrence of agalactia post partum in the sow. Journal of Veterinary Medicine Series A, 36(1-10), 505-513. doi:10.1111/j.1439-0442.1989.tb00760.x

Göransson, L. (1989b). The effect of dietary crude fibre content on the frequency of post partum agalactia in the sow. Journal of Veterinary Medicine Series A, 36(1-10), 474-479. doi:10.1111/j.1439-0442.1989.tb00755.x

Hermansson, I., Einarsson, S., Ekman, L., \& Larsson, K. (1978). On the agalactia post partum in the sow; a hematological and blood chemical study in affected and healthy sows. Nordisk veterinaermedicin.

Houseknecht, K. L., Baile, C. A., Matteri, R. L., \& Spurlock, M. E. (1998). The biology of leptin: a review. Journal of animal science, 76(5), 1405-1420.

Hughes, F. J., Turner, W., Belibasakis, G., \& Martuscelli, G. (2006). Effects of growth factors and cytokines on osteoblast differentiation. Periodontology 2000, 41(1), 48-72. doi:10.1111/j.1600-0757.2006.00161.x

Hultén, F., Persson, A., Eliasson-Selling, L., Heldmer, E., Lindberg, M., Sjögren, U., Kugelberg, C., \& Ehlorsson, C. J. (2004). Evaluation of environmental and management-related risk factors associated with chronic mastitis in sows. American journal of veterinary research, 65(10), 1398-1403. doi:10.2460/ajvr.2004.65.1398

Jenny, B., Vidondo, B., Pendl, W., Kümmerlen, D., \& Sidler, X. (2015). Erhebung von Risikofaktoren für Mastitis-Metritis-Agalaktie in Schweinebetrieben in der Schweiz. Schweiz Arch Tierheilkd. 157(12), 689-96. doi:10.17236/sat00047

Jilka, R. L. (1998). Cytokines, bone remodeling, and estrogen deficiency: a 1998 update. Bone, 23(2), 75-81.

Kamphues, J. (Ed.). (2014). Supplemente zur Tierernährung für Studium und Praxis. Hannover, Germany: Schlütersche. 
Kaur, M., Godber, I. M., Lawson, N., Baker, P. N., Pearson, D., \& Hosking, D. J. (2003). Changes in serum markers of bone turnover during normal pregnancy. Annals of clinical biochemistry, 40(5), 508-513. doi:10.1258\%2F000456303322326416

Kelley, K. W., \& Curtis, S. E. (1978). Effects of heat stress on rectal temperature, respiratory rate and activity rates in peripartal sows and gilts. Journal of animal science, 46(2), 356361. doi: $10.2527 / \mathrm{jas} 1978.462356 \mathrm{x}$

Kierek-Jaszczuk, D., \& Zurkowski, M. (1980). Electrophoretic polymorphism and activity of serum alkaline phosphatase in the ontogenetic development of piglets. Acta physiologica Polonica, 31(4), 375-381.

Klopfenstein, C., Farmer, C., \& Martineau, G. P. (2006). Diseases of the mammary glands. Diseases of swine, 9, 57-86.

Knight, J. W., Bazer, F. W., Thatcher, W. W., Franke, D. E., \& Wallace, H. D. (1977). Conceptus Development in Intact and Unilaterally Hysterectomized-Ovariectomized Gilts: Interrelations among Hormonal Status, Placental Development, Fetal Fluids and Fetal Growth. Journal of animal science, 44(4), 620-637.

Kolp, E., Wilkens, M. R., Pendl, W., Eichenberger, B., \& Liesegang, A. (2017). Vitamin D metabolism in growing pigs: influence of UVB irradiation and dietary vitamin D supply on calcium homeostasis, its regulation and bone metabolism. Journal of animal physiology and animal nutrition, 101, 79-94. doi:10.1111/jpn.12707

Kruse, R., Essén-Gustavsson, B., Fossum, C., \& Jensen-Waern, M. (2008). Blood concentrations of the cytokines IL-1beta, IL-6, IL-10, TNF-alpha and IFN-gamma during experimentally induced swine dysentery. Acta Veterinaria Scandinavica, 50(1), 32. doi: $10.1186 \% 2$ F1751-0147-50-32

Lerner, U. H., \& Fröhlander, N. (1992). Haptoglobin-stimulated bone resorption in neonatal mouse calvarial bones in vitro. Arthritis \& Rheumatism: Official Journal of the American College of Rheumatology, 35(5), 587-591. doi:10.1002/art.1780350517

LfL-Information. 2014. Grundlagen zur Futterberechnung für Schweine, 21. Auflage [PDF file]. Retrieved from http://www.lfl.bayern.de/mam/cms07/publikationen/daten/ informationen/futterberechnung_fuer_schweine_lfl-information.pdf

Liesegang, A., Eicher, R., Sassi, M. L., Risteli, J., Kraenzlin, M., Riond, J. L., \& Wanner, M. (2000). Biochemical Markers of Bone Formation and Resorption Around Parturition and During Lactation in Dairy Cows with High and Low Standard Milk Yields. Journal of Dairy Science, 83(8), 1773-1781. doi:10.3168/jds.S0022-0302(00)75048-X

Liesegang, A., Loch, L., Bürgi, E., \& Risteli, J. (2005). Influence of phytase added to a vegetarian diet on bone metabolism in pregnant and lactating sows. Journal of animal physiology and animal nutrition, 89(3-6), 120-128. doi:10.1111/j.1439$\underline{0396.2005 .00549 . x}$ 
Liesegang, A., Risteli, J., \& Wanner, M. (2007). Bone metabolism of milk goats and sheep during second pregnancy and lactation in comparison to first lactation. Journal of animal physiology and animal nutrition, 91(5-6), 217-225. doi:10.1111/j.1439$\underline{0396.2007 .00695 . x}$

Luimes, P., G. Simpson, \& G. Wideman. (2012). Ketosis in nursery sows. Ontario Pork 2012 [PDF file]. Retrieved from http://www.prairieswine.com/wp-content/uploads/2012/ 08/Ketosis-in-Nursing-Sows.pdf.

Madson, D. M., Ensley, S. M., Gauger, P. C., Schwartz, K. J., Stevenson, G. W., Cooper, V. L., Janke, B. H., Burrough, E. R., Goff, J. P., \& Horst, R. L. (2012). Rickets: case series and diagnostic review of hypovitaminosis $\mathrm{D}$ in swine. Journal of veterinary diagnostic investigation, 24(6), 1137-1144. doi: $10.1177 / 1040638712461487$

Maes, D. G. D., Janssens, G. P. J., Delputte, P., Lammertyn, A., \& de Kruif, A. (2004). Back fat measurements in sows from three commercial pig herds: relationship with reproductive efficiency and correlation with visual body condition scores. Livestock Production Science, 91(1-2), 57-67. doi:10.1016/j.livprodsci.2004.06.015

Maes, D., Papadopoulos, G., Cools, A., \& Janssens, G. P. J. (2010). Postpartum dysgalactia in sows: pathophysiology and risk factors. Tierärztliche Praxis Ausgabe G: Großtiere/Nutztiere, 38(S 01), S15-S20.

Mahan, D. C. (1990). Mineral nutrition of the sow: a review. Journal of animal science, 68(2), 573-582.

Martineau, G. P., Farmer, C., Peltoniemi, O., Ramirez, A., Schwartz, K. J., \& Stevenson, G. W. (2012). Mammary system. Diseases of swine, 10, 270-93.

McPherson, R. L., Ji, F., Wu, G., Blanton Jr, J. R., \& Kim, S. W. (2004). Growth and compositional changes of fetal tissues in pigs. Journal of Animal Science, 82(9), 25342540. doi: $10.2527 / 2004.8292534 \mathrm{x}$

Merk, B. (1992). Einfluß von Alter, Rasse, Haltung, Fütterung und Fortpflanzungsstadium auf Serumenzymwerte beim Schwein. na.

Mirko, C. P., \& Bilkei, G. (2004). Acute phase proteins, serum cortisol and preweaning litter performance in sows suffering from periparturient disease. Acta Veterinaria.

Mullan, B. P., \& Williams, I. H. (1989). The effect of body reserves at farrowing on the reproductive performance of first-litter sows. Animal Science, 48(2), 449-457.

Mullan, B. P., \& Williams, I. H. (1990). The chemical composition of sows during their first lactation. Animal Science, 51(2), 375-387. doi:10.1017/S0003356100005523

Nachreiner, R. F., Garcia, M. C., \& Ginther, O. J. (1972). Clinical, hematologic, and blood chemical changes in swine given endotoxin (Escherichia coli) during the immediate postpartum period. American journal of veterinary research, 33(12), 2489. 
Nanes, M. S. (2003). Tumor necrosis factor- $\alpha$ : molecular and cellular mechanisms in skeletal pathology. Gene, 321, 1-15. doi:10.1016/S0378-1119(03)00841-2

National Research Council. (2012). Nutrient requirements of swine. National Academies Press..

Naylor, K. E., Iqbal, P., Fledelius, C., Fraser, R. B., \& Eastell, R. (2000). The effect of pregnancy on bone density and bone turnover. Journal of Bone and Mineral Research, 15(1), 129-137. doi:10.1359/jbmr.2000.15.1.129

Neil, M., Ogle, B., \& Anner, K. (1996). A two-diet system and ad libitum lactation feeding of the sow 1. Sow performance. Animal Science, 62(2), 337-347. doi:10.1017/S135772980001465X

Nelson, D. L., \& Cox, M. M. (2017). Lehninger principles of biochemistry: International Edition. New York, USA: W. H. Freeman \& Co Ltd

Niemi, J. K., Bergman, P., Ovaska, S., Sevón-Aimonen, M. L., \& Heinonen, M. (2017). Modeling the costs of Postpartum Dysgalactia syndrome and locomotory Disorders on sow Productivity and replacement. Frontiers in veterinary science, 4, 181. doi:10.3389\%2Ffvets.2017.00181

Oliviero, C., Kokkonen, T., Heinonen, M., Sankari, S., \& Peltoniemi, O. (2009). Feeding sows with high fibre diet around farrowing and early lactation: impact on intestinal activity, energy balance related parameters and litter performance. Research in veterinary science, 86(2), 314-319. doi:10.1016/j.rvsc.2008.07.007

Papadopoulos, G. A., Vanderhaeghe, C., Janssens, G. P., Dewulf, J., \& Maes, D. G. (2010). Risk factors associated with postpartum dysgalactia syndrome in sows. The Veterinary Journal, 184(2), 167-171. doi:10.1016/j.tvil.2009.01.010

Pendl, W., Jenny, B., Torgerson, P. R., Spring, P., Kümmerlen, D., \& Sidler, X. (2017). Effect of herd health management on the prevalence of postpartum dysgalaktie syndrome (PPDS) and the treatment incidence. Schweizer Archiv fur Tierheilkunde, 159(2), 109116. doi: $10.17236 / \mathrm{sat} 00105$

Plonait, H. G. (2004). Puerperium und perinatale Verluste. Lehrbuch der Schweinekrankheiten. 4th ed. Hannover, Germany: Parey Verlag, 493-502.

Ruiz, M. E., Ewan, R. C., \& Speer, V. C. (1971). Serum metabolites of pregnant and hysterectomized gilts fed two levels of energy. Journal of animal science, 32(6), 11531159. doi: $10.2527 / \mathrm{jas} 1971.3261153 \mathrm{x}$

Salak-Johnson, J. L., \& McGlone, J. J. (2007). Making sense of apparently conflicting data: Stress and immunity in swine and cattle. Journal of Animal Science, 85(suppl_13), E81E88. doi:10.2527/jas.2006-538

Sarandan, H., Neufeld, N. I. N. A., \& Neufeld, K. (2008). Effects of a new lignocellulose product for fibre supplementation on MMA symptoms, reproductive performance and faecal quality in a pig farm with evident MMA problems in Romania. Lucrari Stiintifice Medicina Veterinara Timisoara, 16, 851-858. 
Schmid, S. A. (2011). Einfluss der Phosphorversorgung auf die Knochengesundheit von Mastschweinen (Doctoral dissertation, Universität Zürich, Institut für Tierernährung der Vetsuisse-Fakultät).

Seutter, U. (1995). Einfluss von Rasse, Haltung, Fütterung, Management, Alter und Reproduktionsstadium auf hämatologische und klinisch-chemische Parameter beim Schwein (Doctoral dissertation, Ludwig-Maximilians-Universität München).

Spurlock, M. E., Ranalletta, M. A., Cornelius, S. G., Frank, G. R., Willis, G. M., JI, S., Alan, L. G., \& Bidwell, C. A. (1998a). Leptin expression in porcine adipose tissue is not increased by endotoxin but is reduced by growth hormone. Journal of interferon \& cytokine research, 18(12), 1051-1058. doi:10.1089/jir.1998.18.1051

Spurlock, M. E., Frank, G. R., Cornelius, S. G., Ji, S., Willis, G. M., \& Bidwell, C. A. (1998b). Obese gene expression in porcine adipose tissue is reduced by food deprivation but not by maintenance or submaintenance intake. The Journal of nutrition, 128(4), 677-682. doi: $10.1093 / \mathrm{jn} / 128.4 .677$

Stiehler, T., Heuwieser, W., Pfützner, A., \& Burfeind, O. (2016). Serum haptoglobin and Creactive protein concentration in relation to rectal and vaginal temperature of early $\begin{array}{llll}\text { postpartum } \quad \text { sows. } & \text { Theriogenology, } & \text { 86(3), }\end{array}$ doi:10.1016/j.theriogenology.2016.03.007

Ulmershakibaei, C., \& Plonait, H. (1992). Studies of lactational hyperthermia in sows. Tierarztliche Umschau, 47(8), 605-611.

Van Abel, M., Hoenderop, J. G., van der Kemp, A. W., Friedlaender, M. M., van Leeuwen, J. P., \& Bindels, R. J. (2005). Coordinated control of renal Ca2+ transport proteins by parathyroid hormone. Kidney international, 68(4), 1708-1721. doi:10.1111/j.1523$\underline{1755.2005 .00587 . \mathrm{x}}$

van Riet, M. M., Millet, S., Liesegang, A., Nalon, E., Ampe, B., Tuyttens, F. A. M., Maes, D., \& Janssens, G. P. J. (2016). Impact of parity on bone metabolism throughout the reproductive cycle in sows. animal, 10(10), 1714-1721. doi: $10.1017 /$ S1751731116000471

Van Soest, P. V., Robertson, J. B., \& Lewis, B. A. (1991). Methods for dietary fiber, neutral detergent fiber, and nonstarch polysaccharides in relation to animal nutrition. Journal of dairy science, 74(10), 3583-3597. doi:10.3168/jds.S0022-0302(91)78551-2

Verheyen, A. J., Maes, D. G., Mateusen, B., Deprez, P., Janssens, G. P., de Lange, L., \& Counotte, G. (2007). Serum biochemical reference values for gestating and lactating sows. The Veterinary Journal, 174(1), 92-98. doi:10.1016/j.tvj1.2006.04.001

Wang, J. F., Wang, M., Ma, J. L., Jiao, L. G., Zhou, X. Y., \& Lindberg, J. E. (2006). The influence of intramammary lipopolysaccharide infusion on serum $\mathrm{Ca}, \mathrm{P}$, vitamin $\mathrm{D}$, cytokines and cortisol concentrations in lactating sows. Journal of Veterinary Medicine Series A, 53(3), 113-118. doi:10.1111/j.1439-0442.2006.00804.x 
Weldon, W. C., Lewis, A. J., Louis, G. F., Kovar, J. L., Giesemann, M. A., \& Miller, P. S. (1994). Postpartum hypophagia in primiparous sows: I. Effects of gestation feeding level on feed intake, feeding behavior, and plasma metabolite concentrations during lactation. Journal of animal science, 72(2), 387-394.

Zhu, Y., Fossum, C., Berg, M., \& Magnusson, U. (2007). Morphometric analysis of proinflammatory cytokines in mammary glands of sows suggests an association between clinical mastitis and local production of IL-1beta, IL-6 and TNF-alpha. Veterinary research, 38(6), 871-882. doi:10.1051/vetres:2007035

Zhu, Y., Berg, M., Fossum, C., \& Magnusson, U. (2007). Proinflammatory cytokine mRNA expression in mammary tissue of sows following intramammary inoculation with Escherichia coli. Veterinary immunology and immunopathology, 116(1-2), 98-103. doi: $10.1016 /$ j.vetimm.2006.12.003

Zhu, Y., Österlundh, I., Hultén, F., \& Magnusson, U. (2004). Tumor necrosis factor- $\alpha$, interleukin-6, serum amyloid A, haptoglobin, and cortisol concentrations in sows following intramammary inoculation of Escherichia coli. American journal of veterinary research, 65(10), 1434-1439. doi:10.2460/ajvr.2004.65.1434 


\section{Danksagung}

Ich danke allen, die zum Gelingen dieser Arbeit beigetragen haben und mit deren Unterstützung ich jederzeit rechnen konnte.

Prof. Dr. med. vet. A. Liesegang für die Möglickeit dieses Thema zu behandeln und die gewissenhafte Durchsicht dieser Arbeit.

Prof. Dr. med. vet. X. Sidler und der Abteilung für Schweinemedizin für die Kontaktdaten der Betriebe und die Beantwortung aller meiner Fragen.

Ines Mittner und Reto Mühlemann für die Analyse aller Proben und die gute Zusammenarbeit.

Besonderer Dank geht an meine Kolleginnen und Kollegen Daniel Hochschwarzer, Camilo Ernesto Pardo, Rahel Rigotti, Angela Gimmel, Monika Bieri und Johanna Freitag für die tatkräftige Unterstützung bei der Probennahme und das Inkaufnehmen der ein oder anderen Verletzung. 


\section{Curriculum Vitae}

Vorname Name Karst Niklas Adrian

Geburtsdatum 23/05/1989

Geburtsort Kirchen (Sieg)

Nationalität Deutsch

08/1995 - 07/1999 Maximilian Kolbe Grundschule Scheuerfeld

08/1999-07/2005 Geschwister Scholl Realschule Betzdorf/Kirchen, Deutschland

08/2005 - 07/2009 Peter-Paul-Rubens Gymnasium, Siegen

10/2010 - 03/2016 Studium der Tiermedizin an der Ludwig-Maximilians-Universität

München, Deutschland

$18 / 03 / 2016$

Bestehen der tierärztlichen Prüfung an der Ludwig-Maximilians-

Universität München, Deutschland

04/2016 - 04/2018 Doktorand am Institut für Tierernährung der Vetsuisse-Fakultät

Universität Zürich, Schweiz

04/2016 - 09/2019 Anfertigung der Dissertation

unter der Leitung von

Prof. Dr. med. vet. Annette Liesegang

am Institut für Tierernährung

der Vetsuisse-Fakultät Universität Zürich

Direktorin: Prof. Dr. med. vet. Annette Liesegang

04/2018 - heute Assistent in der Abteilung für Wiederkäuermedizin der VetsuisseFakultät Universität Zürich, Schweiz 